Title:

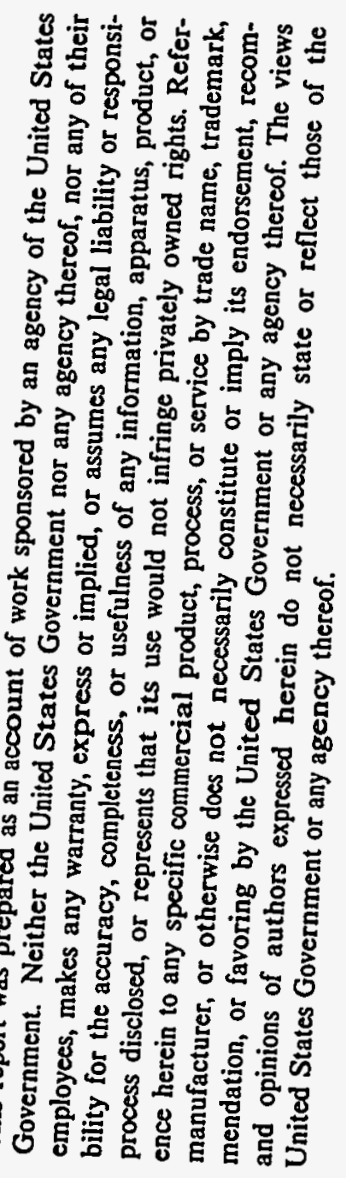

CIECEEVEDE

4u6 29 โุต

(C) 5 . I

Submitted to:
A COMPARISON OF HYDROGEN VEHICLE STORAGE OPTIONS USING THE EPA URBAN DRIVING SCHEDULE
Author(s):

M. A. Daugherty, F. C. Prenger, D. E. Daney,

D. D. Hill, F. J. Edeskuty

Cryogenic Engineering

Columbus, $\mathrm{OH}$

July 17-21, 1995
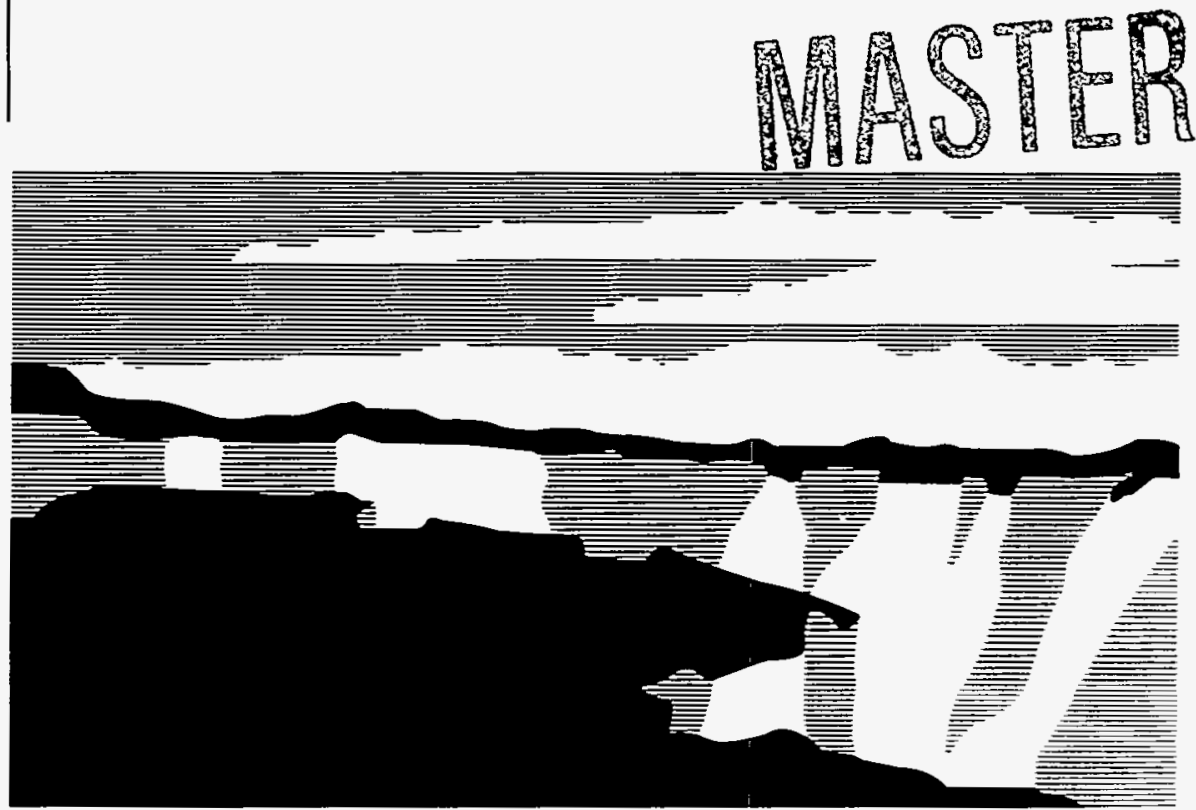

NATIONAL LABORATORY

Los Alamos National Laboratory, an affirmative action/equal opportunity empldyer, is operated by the University of California for the U.S. Department of Energy under contract W-7405-ENG-36. By acceptance of this article, the publisher recognizes that the U.S. Government retains a nonexclusive, royalty-free license to publish or reproduce the published form of this contribution, or to allow others to do so, for U.S. Government purposes. The Los Alamos National Laboratory requests that the publisher identify this article as work performed under the auspices of the U.S. Department of Energy. 


\section{DISCLAIMER}

Portions of this document may be illegible in electronic image products. Images are produced from the best available original document. 


\title{
A COMPARISON OF HYDROGEN VEHICLE STORAGE OPTIONS USING THE EPA URBAN DRIVING SCHEDULE
}

\author{
M.A. Daugherty, F.C. Prenger, D.E. Daney, D.D. Hill, and F.J. Edeskuty \\ Los Alamos National Laboratory \\ Los Alamos, New Mexico, 87545, USA
}

\begin{abstract}
The three standard options for the storage of hydrogen fuel on passenger vehicles are compressed gas, metal hydride and cryogenic liquid storage. The weight of the hydrogen storage system affects the performance of the vehicle. We examine vehicle performance as a function of hydrogen storage system type and capacity. Three vehicles are modeled, a metro commuter, a mid size sedan and a full size van. All vehicles are powered by a fuel cell and an electric drive train. The impact of auxiliary power requirements for air conditioning is also examined. In making these comparisons it is necessary to assume a driving cycle. We use the United States Environmental Protection Agency (EPA) urban dynamometer driving schedule in all simulations to represent typical urban driving conditions.
\end{abstract}

\section{INTRODUCTION}

Historically, on-board storage of hydrogen has been recognized as a major obstacle to the use of hydrogen as a transportation fuel.1.2 Cost, weight and/or volume constraints severely limited the storage of adequate quantities of hydrogen for vehicular applications. Earlier comparisons of the relative merits of different fuel storage systems for hydrogen powered vehicles only considered storage in metal hydrides and cryogenic storage of liquid hydrogen. 3,4 These studies, which examine the use of hydrogen as a fuel for vehicles with internal combustion engines, both concluded that cryogenic storage of liquid hydrogen was the preferred option. The large weight of the metal hydride storage systems resulted in poor performance and increased primary energy consumption for vehicles with ranges in excess of $200 \mathrm{~km}$. The energy penalty incurred by carrying the massive hydride storage system was found to be more than 100 percent for vehicles with a $400-500 \mathrm{~km}$ range. ${ }^{3}$ This result included the energy penalty incurred to liquefy the hydrogen.

Two significant advances led us to reexamine on-board hydrogen storage options. The first is the development of highly efficient and non-polluting fuel cells for transportation applications. 5 Because of the high overall efficiency of fuel cell electric powered vehicles, less hydrogen storage is necessary for a given driving cycle and range. The second advance is the development of light weight high-pressure compressed gas tanks based on composite technology.6,7 These new high performance tanks were originally developed for the aerospace industry and are currently being used for on-board storage of fuel for natural gas vehicles. They are made from high strength graphite composites filament wound over thin seamless liners. 
Table 2. Drive train component masses for $40 \mathrm{~kW}$ fuel cell.

\begin{tabular}{lc}
\hline \multicolumn{1}{c}{ Component } & Mass (kg) \\
\hline Gas Pressurization and Humidification & 34 \\
Fuel Cell Stack & 45 \\
Motor Controller & 41 \\
Motor & 50 \\
Step Down Gear \& Differential & 27 \\
Radiator \& Coolant & 11 \\
\hline Total Drive Train & $\mathbf{2 0 9}$ \\
\hline Total Drive Train (kg/kW) & $\mathbf{5 . 2 3}$ \\
\hline
\end{tabular}

\section{HYDROGEN STORAGE}

The mass fraction of hydrogen each storage system is capable of achieving is the important parameter for the purposes of this study. Mass fractions for metal hydride storage systems found in the literature vary from 0.5 to 4 percent. $10,11,12$ A value of 1.5 percent hydrogen by mass was selected for this study after reviewing the literature. This represents a feasible hydride system such as FeTiMn with a reasonable disassociation temperature.

Literature values for compressed gas storage range from 1 to 6 percent for composite cylinders. 10,11,12 After discussions with Structural Composites, Inc. and EDO Canada, a value of 4 percent hydrogen by mass was chosen for this study. This represents a safety factor of 2.5 for a $33 \mathrm{MPa}(4,800)$ psi composite tank. This is a conservative assumption which exceeds the DOT required safety factor of 2.25 .

Published data on liquid hydrogen storage systems range from 7 to 25 percent. 1,10,11,12,13 Differences in boil off rates and size of the storage tank account affect the mass fraction of hydrogen. For this study we based our liquid hydrogen tank on a $65 \mathrm{~kg}$ tank developed by BMW-DFVLR with a 1.8 percent per day evaporation rate and a $9.2 \mathrm{~kg}$ liquid hydrogen capacity. 12 We did not scale the liquid hydrogen tank linearly. We assumed the tank would be roughly spherical, and that the mass versus storage capacity would scale as the surface to volume ratio of a sphere. Using this method, hydrogen mass percentages vary from 6 percent for $1 \mathrm{~kg}$ tanks to 15 percent for $8 \mathrm{~kg}$ tanks.

\section{VEHICLE MODEL}

The vehicle model computes aerodynamic drag, rolling resistance and kinetic energy requirements at each time step based on the vehicle parameters and the driving schedule velocity profile. 14 The vehicle parameters and the hydrogen storage capacity are read from one input file and the driving schedule velocity profile is read from a second input file. This allows different vehicles to be easily modeled using different driving cycles.

During acceleration the aerodynamic drag, rolling resistance and kinetic energy requirements are all met by the fuel cell. During deceleration some kinetic energy is available to help meet aerodynamic drag and rolling resistance requirements. If enough kinetic energy is available to completely satisfy aerodynamic drag and rolling resistance no power is required from the fuel cell for that time step. Any excess kinetic energy is dissipated by braking. If the kinetic energy available cannot meet aerodynamic drag and rolling resistance requirements the fuel cell contributes the necessary energy. Losses in the drive train are calculated using the efficiencies discussed above. Air conditioning energy requirements are drawn directly from the fuel cell. Figure 1 is a schematic of the energy flows used in the vehicle model.

The mass of the hydrogen storage system is calculated based on the type of storage and the specified fuel capacity. This mass is then increased by 15 percent to account for the mass of the structural supports for the fuel tank. The mass of the drive train is initially estimated based on the size of the fuel cell specified in the vehicle input file. The total vehicle mass is obtained by summing the masses of the drive train, fuel, hydrogen storage system, passengers, and base vehicle. The model then calculates the maximum fuel cell power required to carry this mass over the driving schedule. 


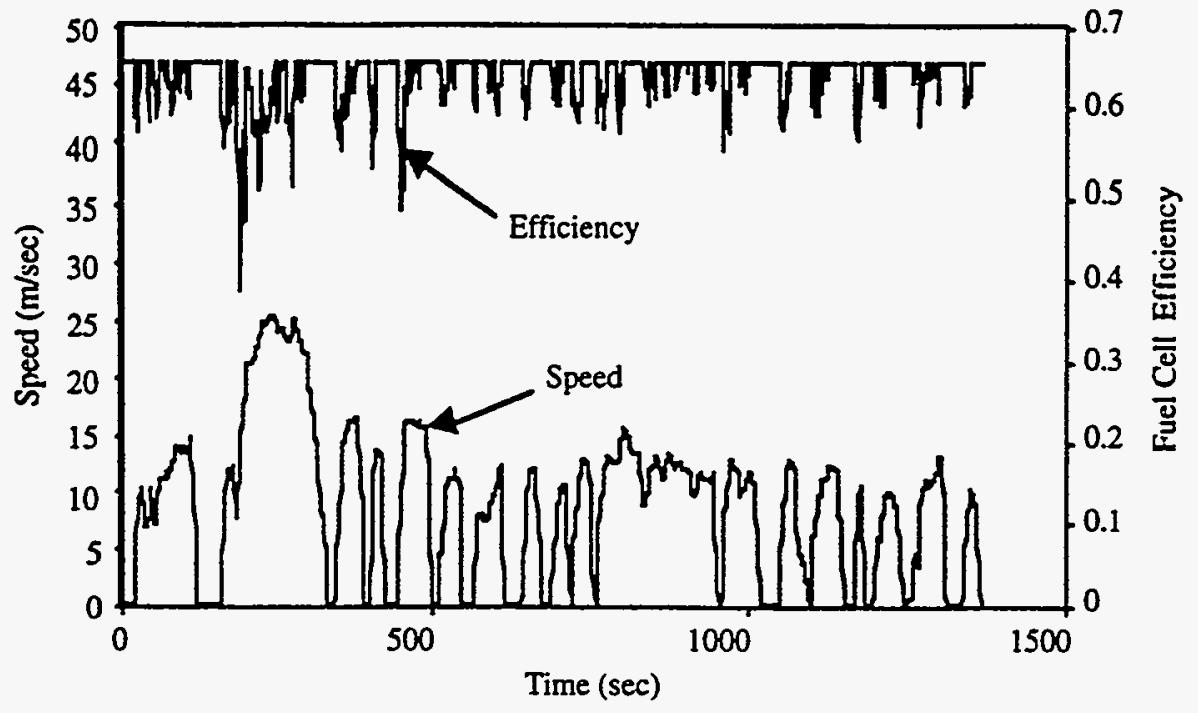

Figure 2. Urban driving schedule and corresponding efficiency.

Figures 3-5 show range as a function of hydrogen fuel storage capacity for each of the three vehicles with and without air conditioning. Air conditioning has a significant effect on vehicle range decreasing it by, on average, 40 percent. In all cases vehicles with liquid hydrogen storage systems have the longest range followed by compressed gas and then metal hydride systems. As vehicle range is increased the impact of storage system weight becomes much more significant. This effect can be seen most clearly in the upper set of plots in figure 3. The difference in range between storage systems is not as pronounced in the cases with air conditioning. This is because the air conditioning power consumption is independent of the weight of the hydrogen storage systems. Figure 6 shows the fuel cell size required for each of the vehicles as a function of hydrogen storage capacity. As hydrogen fuel storage capacity is increased larger drive trains are required to carry the more massive compressed gas and hydride storage systems.

Table 4 shows the hydrogen storage capacity and fuel cell size required for a range of 500 $\mathrm{km}$. For all cases hydride storage requires about 18 percent more hydrogen than liquid storage to achieve the same vehicle range. The difference in required fuel cell size is even more dramatic. For hydride storage systems without air conditioning a 20 percent larger fuel cell and drive train is required and a 30 percent larger drive train is required for the cases with air conditioning compared to liquid storage. Compressed gas storage systems require about 4 percent more hydrogen than liquid systems for a $500 \mathrm{~km}$ range. The drive train for the compressed gas storage varies from 4 to 8 percent larger than that required for liquid storage. Hydride systems thus require significantly larger hydrogen capacities and drive trains to provide the same range and performance. Compressed gas storage systems, however, only require slightly larger hydrogen capacities and drive trains.

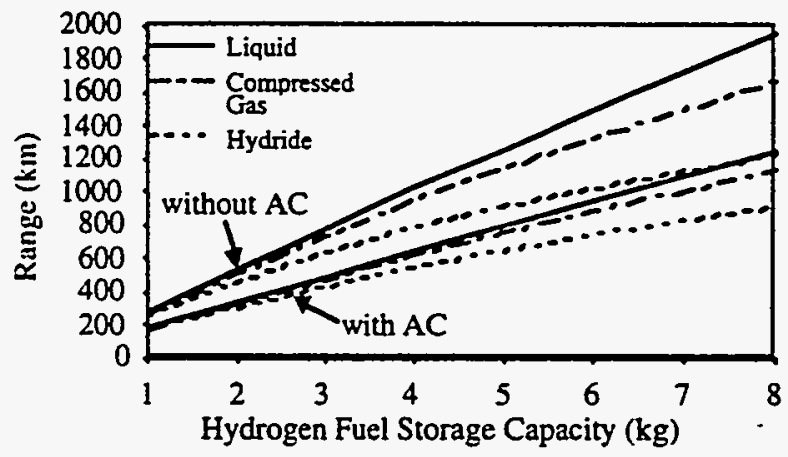

Figure 3. Metro commuter range as a function of hydrogen storage capacity. (Top three curves without air conditioning, bottom three with air conditioning.) 
Table 4. Hydrogen storage capacity and fuel cell size required for a $500 \mathrm{~km}$ range. (Values are without / with air conditioning.)

\begin{tabular}{llll}
\hline & Liquid & $\begin{array}{c}\text { Compressed } \\
\text { Gas }\end{array}$ & Hydride \\
\hline $\begin{array}{c}\text { Metro Commuter } \\
\text { Hydrogen Capacity }(\mathrm{kg})\end{array}$ & $1.96 / 3.14$ & $2.02 / 3.26$ & $2.30 / 3.70$ \\
Fuel Cell Size (kW) & $21.0 / 23.0$ & $21.8 / 24.5$ & $25.1 / 29.8$ \\
\hline $\begin{array}{c}\text { Mid-Size Sedan } \\
\text { Hydrogen Capacity (kg) }\end{array}$ & $3.37 / 5.73$ & $3.51 / 5.99$ & $3.98 / 6.79$ \\
Fuel Cell Size (kW) & $35.5 / 39.4$ & $37.2 / 42.6$ & $42.9 / 52.3$ \\
\hline Full Size Van & $5.91 / 9.83$ & $6.17 / 10.3$ & $7.01 / 11.68$ \\
Hydrogen Capacity (kg) & $61.6 / 68.0$ & $64.8 / 73.7$ & $74.8 / 90.5$ \\
Fuel Cell Size (kW) & & & \\
\hline
\end{tabular}

In general, vehicles with hydride storage systems require approximately 18 percent more fuel and vehicles with compressed gas storage systems require approximately 4 percent more fuel than vehicles with liquid hydrogen storage systems to travel the same distance. Drive trains on vehicles with hydride storage are 20 percent larger for cases without air conditioning and 30 percent larger for cases with air conditioning than those equipped with liquid hydrogen storage. Vehicles with compressed gas storage average 5 percent larger drive trains for cases without air conditioning and 8 percent larger drive trains for cases with air conditioning than vehicles with liquid hydrogen storage.

These results show that the high efficiencies achievable with fuel cell electric drive vehicles and the recent advances in light weight composite compressed gas tanks allow vehicles equipped with compressed gas storage to approach the performance of vehicles equipped with liquid hydrogen storage. Even with highly efficient fuel cell drives the vehicles with hydride storage systems incur significant performance penalties requiring substantially more fuel and larger drive trains. On vehicles with less efficient mechanical drives the performance penalties would be much larger.

\section{ACKNOWLEDGMENTS}

This work was supported by Los Alamos National Laboratory Directed Research and Development funding.

\section{REFERENCES}

1. W.F. Stewart, Operating Experience with a Liquid-Hydrogen Fueled Buick and Refueling System, J. Hydrogen Energy, vol. 9, no. 6, p. 525 (1984).

2. W.J.D. Escher, Survey of Liquid Hydrogen Container Techniques for Highway Vehicle Fuel System Applications, U.S. Department of Energy Report, no. HCP/M2752-01 (1979).

3. C. Carpetis, Comparison of the Expenses Required for the On-Board Fuel Storage Systems of Hydrogen Powered Vehicles, Int. J. Hydrogen Energy, vol. 7, no. 1, p. 61 (1982).

4. J.J. Donnelly, W.C. Greayer, R.J. Nichols, W.J.D. Escher, and E.E. Ecklund, Hydrogen-Powered vs Battery-Powered Automobiles, Int. J. Hydrogen Energy, vol. 4, p. 411 (1979).

5. B.D. James, G.N. Baum, and I.F. Kuhn, Jr., Technology Development Goals for Automotive Fuel Cell Power Systems, Argonne National Laboratory Report, no. ANL-94/44 (1994).

6. S.N. Sirosh, Application of Advanced Composites for Efficient On-Board Storage of Fuel in Natural Gas Vehicles, Proc. Int. Conference on Composite Materials and Energy, Montreal, Quebec, Canada, p. 793 (1995). 


\section{Mark--}

LA-UR 95-2461 Assembly \& testing of a composite heat pipe 2462 comparison of hyrdrogen vehicle

2463 Coyne

2464 Dave Daney

Borup 95-2483

Kirk 2484 